\title{
Benjamin's KISS: A Perspective on Music, Spectacle and Aura
}

\author{
Rob Ahlers \\ University of Groningen \\ r.ahlers@rug.nl
}

\begin{abstract}
This article explores the ontological significance of spectacle and imagery in rock music. The examination illuminates how the construct of a larger-than-life fantasy and a live performance spectacle creates a sense of auratic presence; in other words, how live performance creates a present-moment experience and a sense of being in the here and now with an authentic and original work of art. Such characteristics, as encapsulated in Walter Benjamin's concept of "aura", have been considered problematic or even no longer relevant. However, I will argue here that in our age of digital reproduction the aura persists and is not irrevocably lost in reproduction. Moreover, the aura is transportable and present in the $21^{\text {st }}$ century live music economy, as the case of the American rock group KISS will illustrate. By analysing KISS' marketing strategy in the 1970s and how it evolved from there into the branding, licensing, and merchandising franchise that it became during the late 1990s, this article will show what a music group can do to auratically appeal to an audience by using (and leveraging) media strategy, mysticism, and the appearance of success.
\end{abstract}

KEYWORDS: KISS, Benjamin, aura, liveness, spectacle, live performance

The combustible mix of personalities in KISS created an unusual dimension to their appeal, transcending what came across in their records. Building the hype for the band succeeded by exploiting this chemistry and connecting it to their visual image and the mystique of their live shows ... KISS' constant regimen of touring and seeing their fans in the flesh was crucial to the success of this image. (Lendt 1997: 48) 
The bombs explode, the lights flash, the fireworks shoot into the sky. To the uninitiated, a KISS concert is an assault on the senses, a decibel blitz and a visual invasion. To their fans, a KISS show is a high mass and most anybody attending their first KISS concert is converted. The lure of the carnival is irresistible. A KISS concert is a combination of Halloween, the Fourth of July, and a trip to the circus, and it's as full of wonderful surprises as Christmas morning. (Leaf and Sharp 2003: 2)

\section{Introduction}

As the quotes above exemplify, a KISS live performance is a multi-sensory concert experience. To fully understand and grasp KISS' success, it is therefore crucial to analyse its performative qualities. In academic discourse, live performance is a relatively new field of study. Since popular music started to gain scholarly attention in the 1980s, most research has focused on sociological, historical, or media perspectives. The category of live performance, however, has received minimal attention. As Philip Auslander (1999), Simon Frith (2007) and Fabian Holt (2010) have shown, the live performance economy has become an important factor in the current context of digitalized music distribution. Holt (2010: 253) argues that live experience - and particularly live music - has gained greater cultural value in contemporary culture. Performance is a unique experiential category and a specialized practice within distinct domains of cultural production. And since performance offers physical, bodily co-presence in a social and material space, stage performance offers a contrast to the "noisy" and disembodied spaces of communication in the digital information society. With reference to Walter Benjamin's notion of "aura", Holt (2010: 245) posits that live music is associated "with culturally and commercially valued performance in a desired time and space".

In 1936 Walter Benjamin wrote his well-known essay The Work of Art in the Age of Mechanical Reproduction. ${ }^{1}$ Benjamin's essay is an inquiry into the consequences of emerging media technologies for art and culture. He argues that film and other then-new mechanical technologies cause an original artwork to lose its unique and authentic "genuineness", a singular quality and presence in time and space that Benjamin encapsulates by using the term "aura". Benjamin (2008: 7) defines an artwork's aura as "the quintessence of everything about it since its creation that can be handed down, from its material duration to the historical witness that it bears". Reproductive technology, Benjamin argues, removes the thing reproduced from its original historical context, from the realm of tradition and its ritual function. Benjamin (2008: 7) states: "In making many copies of the reproduction, it substitutes for its unique incidence a multiplicity of incidences". And further on: "This process ... frees the work of art, for the first time in history, from its existence as a parasite upon ritual" (2008: 11-12). This converts the work of art's original "cult value" into "display value".

Douglas Davis (1995) and Jay David Bolter et. al. (2006), however, have argued that aura is not unconditionally lost in modern reproductive society. In fact, digital technology allows the invocation of aura in new ways and 
reproductions have firmly found their place in our modern art world. ${ }^{2}$ What has remained undisclosed, however, is how Benjamin's aura theory relates to live musical performances. Can live performance evoke auratic experience? How would stardom and fandom dynamics affect this process? And in what way do imaging, mediation, and marketing strategies manipulate these mechanisms? In this article I invoke Walter Benjamin's notion of aura and Holt's insights into the economy of live music as starting points, and use these to analyse one of the most influential rock bands of the 1970s and afterwards: KISS. I aim to provide insight into how aura theory can provide an analytical lens through which the immense success of one of the most branded and licensed bands of all time can be explained (Barfoot 2011). After all, as early as 1938 Theodor Adorno (2002: 298299) claimed that the aura has not been eroded, but merely transferred from the work of art to star performers. Using KISS as my case study, I argue that the aura persists and needs to be reconsidered and modernized in the context of $21^{\text {st }}$ century mediated performance standards. I will explore facets of ritual, connected to performativity, gender and fandom. Also, I will provide insight into how the auratic live performance experience is channelled through marketing techniques such as mythologisation and illusion.

The case study is divided into two parts. The first part will focus on KISS' rise to stardom in the 1970s. The second part focuses on how KISS builds on sentiments of nostalgia and glorification for their success in the increasingly digitalized and globalized latter half of the 1990s until the present.

\section{Glam rock and the construct of identity}

The visual language of metal album covers and the spectacular stage shows offer larger-than-life images tied to fantasies of social power, just as in the more prestigious musical spectacles of opera (Walser 1993: 2)

From the very beginning in January 1973, when KISS decided to paint their faces with makeup and construct their alter egos, the concept of the band was just as important as the music they played. The four original band members - Gene Simmons (alias The Demon), Paul Stanley (alias The Starchild), Peter Criss (alias The Catman), and Ace Frehley (alias The Spaceman) - decided to, as Gene Simmons recalls, "put together the band we never saw on stage". It had to be an audiovisual experience, not just four musicians playing their instruments. It is also significant that in its earliest stages KISS maintained an androgynous image, which was mainly copied from early glam rockers The New York Dolls. "Glam" refers to the visual aspect that characterizes the groups that are ranked among this genre. Their distinguishing features constitute wearing colourful costumes, a melodic musical style, and the rejection of the outlaw fashion that was then the dress code within the heavy metal scene (Weinstein 1991: 46). David Bowie, The New York Dolls, and Alice Cooper were established names in the glam rock circuit in the early 1970s and these groups are regarded as the most important influences for KISS' early theatrical performance aesthetics. The glam image was quickly changed by KISS, however, to a black and white theme after seeing the New York Dolls in concert, because as Gene Simmons (Sharp 2013: 84) explains: "we 
realized we weren't gonna beat the dolls at their own game". And, as Simmons (2003: 59) states in his autobiography:

We were really enchanted with the concept of being able to immerse yourself
into your own fantasies and come out of it a completely different person, and
yet the same person. ... As KISS became more comfortable in this second
skin, we started to see how powerful our new look really was, and how it
moved far beyond glam rock, which was already feeling as though it was
running its course.

Although in their early stages KISS distanced themselves from the glam rock aesthetic, it is useful to recognize how glam rock, identity, and live performance mutually informed each other, as this is important for how mythification comes into being. Philip Auslander (2006) theorizes how glam rock artists promoted themselves as performers and how they relate to their audience with these performances. Auslander (2006: 40) argues that glam is a rock subgenre that developed within a movement that rebelled against the "ideology of authenticity" in psychedelic rock. In the psychedelic movement, rock is perceived to be an authentic musical style, and it offers refuge to its followers who rebel against the alienating effects of the political establishment. Auslander (2006: 40), however, argues that authenticity is not an ontological quality of rock, but that this is created through performance. ${ }^{3}$ Glam rock acknowledges this performance aesthetic and uses it to question conventional conceptions of gender, identity, and authenticity.

Another interesting perspective comes from Robert Walser (1993: 124), who explains androgyny in rock and metal as "the adoption by male performers of the elements of appearance that have been associated with women's function as objects of the male gaze - the visual styles that connote "to-be-looked-at-ness". What groups in the glam rock genre have in common is this androgynous image. For the first time in rock's history, men started putting on makeup. Although performers like Little Richard, Elvis Presley, and The Rolling Stones were known to have worn makeup during some periods, glam rock turned it into a distinguishing stylistic feature. According to Walser (ibid.), the heavy metal genre generally lacks ironic distance. It is the absence of this irony that caused critics to scorn the glam genre, "for the ridiculous seriousness of metal's gender constructions is at odds with the patriarchal premises undergirding the ideologies and institutions of rock". In 1970, this lead to the much-discussed David Bowie's The Man Who Sold the World album cover, and to New York Dolls lead singer David Johansen, who would dress up in drag during live performances. These androgynous characteristics can also be seen during KISS' early experimental stages.

KISS, too, seemed to lack irony in their appearance. Moreover, KISS was dead serious in conveying their created characters. They did not use their identities as tactics to deal with latent fear of the pressures of masculinity or to appropriate feminine visual aesthetics and the "powers of spectacularity", as Walser puts it. More than any of this, the lack of irony in KISS' constructed personae can be traced to their vision for the band - their unambiguous dream to become a worldwide mega-act, new icons of American cult society, modelled after the 
larger-than-life imagery of comic book heroes and the mythological success of Walt Disney's characters. Gene Simmons (2003: 83) recalls: "we talked to [...Casablanca record label owner Neil Bogart] for a while and explained our vision of the band, which was to go beyond glam to something else. In a strange way, our greatest asset was that the fact that we took our look seriously. Superman wore tights and a cape, and no one ever questions his sexuality because he didn't see his costume as campy or funny - it was just what superheroes wore".

This "strange way" that Simmons mentions, however, might refer to the notion of "reflexive anti-reflexivity", as theorized by Keith Kahn-Harris, which sheds a different, more recent, light on the issue of ironic distance. Kahn-Harris (2007: 143) describes reflexive anti-reflexivity as "the coexistence of determinedly reflexive and unreflexive practices within the scene". In other words, certain rules, codes or behaviours can be maintained and protected, while their illusory natures are acknowledged at the same time. This, however, does not reduce the commitment of members to the scene. In fact, scene members can wilfully ignore contradiction and inconsistency in the interest of determining borders, and can generally provide a clear definition of what they consider to be inside and outside the scene. In Kahn-Harris' (2007: 145) words: "If unreflexivity is 'not knowing better' and anti-reflexivity is 'not wanting to know', then reflexive anti-reflexivity is "knowing better but deciding not to know'".

In KISS' case, the integration and operation of the super hero illusion might be closely associated to camp, that is, to deliberate and self-acknowledged theatricality. At the same time, credibility is not lost in this cultivation of parody, and as Kahn-Harris (2007: 151) puts it, "the humorous never undermines the serious". Indeed, for the members of KISS, their appearance exemplified universal values of freedom and self-empowerment. As with iconic characters from Walt Disney, or fantasy figures from comic books, mythification, heroism, recognisability, and hyper reality were key ingredients to make an audience believe - and invest - in this illusion.

\section{Beatles on steroids}

Another major influence on both KISS' music and their image aesthetic were The Beatles. KISS liked to see themselves as the "rockier" version of the British group with whom the KISS members grew up musically. "We wanted to become The Beatles on steroids, with lots more makeup and higher shoes," as Gene Simmons (Something Else! 2012: web source) put it. Besides the musical aspect, the Beatles' group model also served as an example for KISS. In The Beatles, each band member was a vocalist and had his own personal identity. Each was also a star individually, in contrast to the more traditional format where there would be a lead singer who was backed up by an accompanying band. George, Paul, John, and Ringo became Gene, Paul, Ace, and Peter in this band model. The concept that someone could be a fan of the whole band, but also of one member in particular opened up a whole range of commercial opportunities. It was the perfect template for KISS in terms of marketing and merchandising possibilities. Imaging, hype, and creating a synergetic relationship between the four individual 
characters became the key media strategy to promote KISS and to create a "buzz" and aura surrounding the band.

KISS' theatrical stage act was worked out in great detail. By making use of video recordings and videotaping band rehearsals, their stage presence was analysed in depth. New choreographies and theatrical acts were invented and developed with manager Bill Aucoin and his assistant Sean Delaney operating as the creative visionary force. In KISS' stage show, Gene Simmons constituted the undisputed centre of attention. With his demonesque appearance he roamed the stage wiggling his (extremely) long tongue. Also, he flew through the air, breathed fire, and performed a blood-spitting act. Besides that, the live show was characterized by its use of fireworks, pyrotechnics, smoke bombs, confetti, smoking guitars and moving stage parts. Also, the band members decided to keep their true identities hidden, to sustain their mystic and supernatural image. As Gene Simmons (2003: 55) recalls: "They wanted superman, not Clark Kent. So we started to hide our real faces, which only fuelled the mystique". Therefore, KISS decided to no longer appear in public without makeup, which gave them a largerthan-life, mystical aura and a kind of comic book quality. To reach the audience, KISS embarked on an exhaustive touring schedule. Since it was very hard to get airplay, the idea was to build a foundation by being a grassroots band.

\section{A grassroots strategy to building the KISS Army}

What irony: people originally intended to use the record to preserve the performance, and today the performance is only successful as a simulacrum of the record. (Attali, 1985: 85)

Most rock groups in the 1970s built their following by constant touring. The rock and metal scene did not thrive on airplay, but mostly relied on playing increasingly spectacular live shows (Walser 1993). These live shows also played an important part in rock culture for an artist's claim on authenticity and credibility, as Philip Auslander (2008: 88) explains: "While recordings and the visual artifacts of rock culture proffer evidence of authenticity, only live performance can certify it for rock ideology". KISS, too, built its following in large part on the road, also playing in the smaller and medium-sized cities that other bands would disregard. As one of KISS' first touring crewmember recalls:

We'd play clubs, ice skating rinks, cafeterias, small theatres - anyplace that would have us, we'd be there. And if that meant we had to play a bunch of off-the-map towns, we'd do it. For a lot of the fans couldn't afford to get to the major cities we'd bring the show to them. ... It was an exponential progression on a grassroots level and was a crucial element toward building their popularity. (Sharp 2013: 420)

Local media were often glad that something newsworthy occurred in their sleepy little towns and gratefully utilized the opportunity to provide KISS with media exposure, during which KISS painstakingly cultivated a crude and mystic image. 
Their lyrics enhanced this crude image even further. Singing about partying, sex, freedom, and self-empowerment were antagonistic anti-establishment themes that specifically appealed to the hard working middle class demographic. The fact that music critics disliked the band and hardly paid any attention to them was an important factor as well. KISS became a people's band, a band the working class could identify with. ${ }^{4} \mathrm{KISS}^{\prime}$ former financial manager Chris Lendt (1997: 69) emphasized this image in his book Kiss and Sell:

\begin{abstract}
The KISS message was that there was no message, no subtext, and no subtleties. Which is what the kids wanted to hear. You could read anything you wanted into Kiss - sex, partying, pleasure seeking, rebelling, aggression. Kiss' attitude sent out the signal to fans that it was okay to cut loose and let it all out for a few hours in a jam-packed arena, immersed in a frenzy of blinding lights, crushing sound, and ear-splitting explosions, before returning to the drudgery and dreariness of their lives.
\end{abstract}

The loyalty of their fans has always been of great value for KISS. The fans call themselves the "KISS Army", which describes their limitless devotion to the group's heritage. The KISS Army was officially founded in 1975, two years after the band's formation, by two loyal fans in Terre Haute, Indiana. They persisted in contacting the local radio stations, demanding that they'd play KISS' music. This intensive lobby proved successful. KISS received a lot of media attention prior to their ultimately sold-out concert in Terre Haute on November $21^{\text {st }} 1975$ and the event marked the definitive break-through of the KISS Army fan club. During its peak in 1978, the fan club consisted of 100,000 members and grossed 5000 dollars a day in albums and merchandise sales (Leaf and Sharp 2003: 158).

In the period between 1973 and 1975, KISS reserved much time during their tours for the local press, for promotional purposes. They willingly posed for pictures and gave animated interviews, which resulted in headline stories in daily papers and often a lead story on local television. Most small and intermediate cities were in constant need of newsworthy topics and KISS was the perfect subject, causing a stir with kids and creating a nuisance for local authorities. Remarkably, local media often cooperated and assisted in promoting the KISS hype. Moreover, this mystical aura boosted newspaper sales. So, as long as the gimmick fulfilled reader's interest, the media delivered the story. The band members' true identities were kept a secret. In turn, journalists and TV producers who helped create - or sustain - the KISS illusion were rewarded with exclusive stories and scoops. It was the ideal quid pro quo (Lendt 1997: 40).

KISS' album sales depended heavily on their reputation as a live act. As Robert Walser (1993: 10) explains, rock fans have always been loyal concert goers, and metal and rock groups built their fan base by means of an exhaustive touring schedule. ${ }^{5}$ Between 1974 and 1984 KISS made nineteen albums, seventeen of which went gold (thirteen went platinum) with virtually no airplay. This sparked the idea of Bill Aucoin and the Casablanca label to release a live album. The idea was to give the fans a sonic souvenir after attending the live concert. Thus, the intense experience of a KISS concert would be relocated from the arena to the living room. In the next section I will elaborate on the production process - the 
visual, experiential qualities, and sonic enhancements - of this live album, before moving back to the topic of aura.

\section{The liveness of Alive!}

In early 1975 KISS' record label Casablanca Records was close to bankruptcy. Although Kiss was established as a live act with increasing attendance rates, this success was not reflected in album sales. According to fans and critics, the music and sound of KISS' studio albums lacked the energetic and exciting atmosphere that was so characteristic of the live shows. So manager Bill Aucoin and Casablanca came up with an emergency plan: the release of an auditory live show souvenir - the double live album KISS Alive!. The album was meant to serve as an ode to KISS'S successful live reputation. It was recorded during four live shows from May to June 1975, and was released on September $10^{\text {th }}$ of that same year. It marked KISS's definitive commercial breakthrough. In the first months after its release the album sold approximately 1.5 million copies (Sharp 2013: 197). The song "Rock and Roll All Nite" was released as a single and reached number twelve on the Hot-100 Charts. KISS Alive! engineer Eddie Kramer recalls the amazement about the sudden success:

Because of KISS's fan base, we thought the album was gonna do okay. Maybe it would sell 250,000, 300,000 copies, which would be very respectable. Then, of course, the album took off like a bloody rocket and did half a million, then a million, two million, and wound up selling over four million copies. Everybody went crazy. Alive! sold way beyond our wildest expectations (Sharp 2013: 112).

The astonishment was even greater due to the fact that very few bands who released a live album in the early 1970 s were considered legitimate and credible. When a live album was released it was almost always put out to fulfil contracts, as Gene Simmons (2003: 112) recalls. As rock's live performance spectacle developed in the 1970s, the desire to capture this live performance aesthetic on vinyl increased. The popularity of live albums and bootleg recordings emerged as a result. Bootlegs gratified this desire for liveness and authentic experience and were highly collectible. KISS was one of the first groups to regard a live album as a serious artistic product; and exerted considerable effort towards making it a success. The release and the success of KISS Alive! had great implications for rock's record industry of the 1970s. Other bands followed with official live releases, for example Peter Frampton's Frampton Comes Alive (1976), Cheap Trick's Cheap Trick at Budokan (1978), and Aerosmith's Live! Bootleg (1978). Since the early 1970s, live albums and live bootlegs have been accepted as part of rock culture and Kiss Alive! was an important contribution to that transformation.

KISS Alive! was a turning point in that it was the first KISS album cover to be designed by marketing experts at an advertising agency. The cover showed all three studio albums (which began to sell more briskly after KISS Alive!'s success), a picture of handwritten notes from all four band members, and colourful inner 
sleeves. Also, contrary to rock's conventions, KISS Alive! was released as a gatefold double album. It was a well thought-out, visually exciting package. Visual artist Dennis Woloch designed the album cover. He recalls: "I came up with the stencil lettering for Alive! because that looked like it was impromptu, like it was very rushed. Instead of 'side one' or 'side two' I came up with 'One, Two, Three, Four,' almost like a musician counting off a song: 'One, Two Three, Four!' (Sharp 2013: 404). With this, it had to breath liveness and immediacy.

Another notable marketing strategy, which will take us back to the debate on aura, was the fact that KISS Alive! was enhanced with studio sound effects in the mixing process. The aim was to give the listener a more immersive and 'realistic' sense of the actual live concert. As former Casablanca vice president Buck Reingold recalls: "When you went to a KISS show and you sat in the audience, you not only saw them but you felt them. It was a physical experience as well as one of sound and visual" (Sharp 2013: 285). KISS Alive! was meant to become the ultimate auratic substitute for physical presence. When you closed your eyes you could hear the echoes and feel the bombs explode in your living room as if standing in the field. In his autobiography, lead vocalist Paul Stanley (2014: 173) discusses this claim of authenticity for KISS Alive! in relation to the postproduction alterations:

[Y]es, we enhanced it. Not to hide anything, not to fool anyone. But who wanted to hear a mistake repeated endlessly? Who wanted to hear an out-oftune guitar? For what? Authenticity? At a concert, you listen with your ears and eyes. A mistake that passed unnoticed in the moment lives forever when recorded. We wanted to re-create the experience of our show - whatever needed to be done, we did it. The flash pots were enhanced with recordings of cannons, because that's what they sounded like in person. The audience was jacked up to immerse the listener in the crowd. It was the only way to replicate our concert-on-steroids. We figured the people who celebrated with us at a concert wanted to hear what they remembered, what they perceived.

This statement about the post-production of KISS Alive! is an interesting contribution to the discussion about truthfulness in representation and about claims of authenticity. KISS's goal with Alive! was to recreate the aura of being present at the actual live performance by enhancing 1970s reproduction techniques. It had to capture the live experience in terms of what it felt like in the audience, which was the quality of a communal celebration. This provides an interesting connection to the ritual and religious function that Walter Benjamin inextricably links to an auratic work of art. If, according to Benjamin, original, auratic art draws its validity from "cult value", KISS Alive! was created to represent just that. "It's like a church revival; it's trying to get everybody to peak together. Alive! really spotlights the experience not only in terms of what the band was doing but what the audience was doing," as Paul Stanley (Leaf and Sharp 2003: 243) puts it. Therefore, I would argue that, in Benjamin's cultic sense, KISS Alive! served as the relic of a worship ritual, an auratic sermon that would remind the listener to celebrate life and Rock and Roll. Or, as Epic Rights branding and marketing executive Evan Stanley sums it up: "Up until that point, live albums gave the fans the sound of their favorite band in concert, Alive! gave fans the experience" (Stanley n.d.: web source). 
However, KISS Alive! was not a success solely because of the souvenir purpose it was meant to serve, but also because of the thriving live show attendance incentive. Not only did the technical manipulation of KISS Alive! create an illusory super star caricature, but the collective set of built up expectations based around KISS's mythology lead to - not simply an expectation of fun and spectatorship - but to auratic experience. As a result, merchandise and collectibles sales multiplied and concert attendance numbers increased dramatically. The band had to live up to this super star image during the live shows, which made their stage presence and overwhelming show elements all the more important to enhance the audience's immersive live experience.

\section{Benjamin's KISS}

The search for the new, modern aura that is undertaken in this article is not unprecedented. In his aforementioned inquiry into liveness, for example, Philip Auslander elaborates on modern media techniques and the consequences for Benjamin's notion of aura. Auslander (2008: 117-118) states that in the process of digital reproduction, the distinction between original and copy dissolves. Thus, a digital copy is not an inferior reflection of its original, but a form of cloning:

Digital code is reproduced through a process of "cloning", the information on all compact discs and their sources is identical: all are "originals"; there is neither an originary referent nor a first in the series. (In a reproductive process, one can speak of a "parent." A Clone, however, is a simulation, the replication of a model, not the offspring of a parent).

In this process, Auslander argues, the aura is not destroyed, but there is the emergence of a new, transportable, aura - an aura that can be instigated and refreshed and experienced infinitely.

Jay David Bolter et.al. (2006) also argue that aura is not completely lost in the modern digital era, for the same reasons: in digitalization the exact same experience can be transferred to its users. Therefore, Bolter et.al. conclude, reproduction does not lead to the absence of aura by definition, but every copy or reproduction can be judged on auratic presence. Bolter et. al. (2006: 34) call this the ability to evoke authentic experience: "[T]he desire for immediacy and for auratic experience has paradoxically survived in the face of increasing levels of mediation that technology makes possible". Walter Benjamin's analysis of how aura is established is no longer tenable in the modern era of technological and multimedial possibilities. The aura is not lost, and can be experienced in various degrees. Moreover, permanent loss of aura will never happen, for "each media is constantly comparing itself with other older and newer forms" (ibid).

Lastly, Douglas Davis (1995) also argues that there is no longer a distinction between the original and the copy in the digital era. Digital reproduction techniques allow the viewer to create their own unique experience and perception of aura. The insoluble connection of the artwork with its unique time and place persists, but it is transportable and repeatable. In Davis' (1995:18) words: "Even now, in an age when copying is high art, when the simple physical 
availability of vintage masterpieces is dwindling, when postmodern theories of assemblage and collage inform our sensibility, the concept of aura persists". The aura lives on in reproductions and performances.

In the $21^{\text {st }}$ century, live concerts are perceived and expected to be total experiences. In other words, to be not just music but a show in which crossdisciplinary artistic elements (for instance, theatre, acting, music, dance, and film) are combined with modern production techniques, digital media, and often other supplements such as food and drink. Also, the selling of merchandise has become an important factor. The unique, one-off auratic experience of the concert is linked to merchandise and used as a sales technique. For example, T-shirts were for sale at each KISS concert and had a specific print stating the date, city and the added phrase "I was there!". Another example is that there would be an instant CD pressing installation present near the venue exit at each of the KISS concerts during the Alive/Worldwide Tour in 2008, where fans could buy a recording of the very concert they had just attended a few minutes ago.

As Simon Frith (2007) has argued, a concert tour is no longer necessarily the consequence of having a successful album, but the releasing of a new album is a justification to initiate a tour. Today, the live concert is an important source of income for an artist, especially since the emergence of the Internet, download culture, and media streaming platforms have caused the record industry to decline. The case of KISS shows how these technological changes in the music industry can be implemented in marketing strategies to create a successful live performance aesthetic, using aura as an imperishable catalyst.

\section{Media blitz: from KISS to Super KISS}

In early 1976, the success of KISS Alive! marked a new phase for the band. In order to develop new promotional strategies for the group, Bill Aucoin developed a new media offensive in which portraying the members of KISS as comic book heroes, along with a greater emphasis on merchandise and collectibles, would be important elements. Due to KISS's visual appeal, this form of marketing would be the logical next step. Simultaneously, the live show became bigger and more spectacular, involving more pyrotechnics, sound effects and on-stage theatrics. KISS became super KISS, and that was to be the message the media should bring forward from that time on, as Chris Lendt (1997: 39) recalls:

That was the whole point - not just making KISS big, but making it seem bigger than it really was. With Alive! at the top of the charts, the strategy was paying off. The perception of KISS created by the media was that of a supergroup in a league of their own. Other groups sold comparable amounts of records and tickets ... but KISS was perceived to be bigger because it dominated the media through hype. And everything in KISS was measured in millions - millions of dollars, millions of tickets, millions of records, millions in stage gear, and millions of fans.

To match such criteria, KISS hired top producer Bob Ezrin for the follow up album. Ezrin had previously achieved success in producing albums for Alice 
Cooper and Aerosmith and was perceived to be the creative engineer that could bring KISS's artistic aspirations to the same levels of rock super-stardom. Not only did his vision and working regime make a difference, but his progressive recording methods also helped to make the album musically diverse and experimental. The bombastic straight ahead rock which KISS was known for was given increased density by adding sound effects, choirs, piano and string arrangements. Destroyer was released on March 15, 1976. Remarkably, the only song on the album where no guitars or drums were used became KISS's highest charting single in the US. "Beth" reached no. 7 in the Billboard Charts and won a People's Choice Award on March 5 1977.

Visual artist Ken Kelly was hired to design the album cover for Destroyer. Kelly was well known for his horror and fantasy comic book drawings in magazines like Creepy and Eerie Magazine. The concept was to portray the band members on the cover as comic book heroes, in accordance with the new promotional course that was set out to scale KISS up to "Super KISS". On the cover KISS are shown as conquerors, dancing on the remains of an apocalyptic battle, without any instruments. Gene Simmons (2003: 262) recalled: "It said, in effect, 'We are more than the guitars we play'. It was the pivotal moment that sent a message out to millions of fans and press alike - we are also superheroes".

The creation of this illusion intensified the KISS myth, thus increasing the gap between the marketed and mediatized KISS and its "real" live performance. This provides an interesting link to Walter Benjamin's notion of the "actor". Here, Benjamin links the consequences of mediated hyper reality for auratic experience to film and theatre, where film techniques transform the actor's persona characteristics and successively impact his/her overall performance. Film mediates the image of the actor in ways that would be impossible in theatrical performances, thus changing the spectator's performance experience. In Benjamin's (2008: 24) words: "[A film] portrays an event that can no longer be assigned to a single standpoint from which things not strictly belonging to the performance process as such ... would not fall within the spectator's field of view". Therefore, "the illusory nature of film ... derives from editing". Linked to KISS's music performance, one could argue that film corresponds to studio albums, while the live performance is linked to theatre. In other words, KISS's mediatized image is the filmic counterpart of its auratic theatrical live performance spectacle.

The KISS-hype continued to grow after the release of Destroyer in 1976. And so did the marketing machine; the supply and sales of KISS merchandise reached new heights. Suddenly, you could buy KISS action figures, radios, lunch boxes, make-up kits, Halloween costumes, and pinball machines, and the list goes on. Also, Marvel Comics published a full colour comic book about the band in 1977, presenting them as super heroes who possessed supernatural powers. As a publicity stunt, blood was drawn from each band member and poured into the vats of red ink used for printing the comic's first edition at Marvel's Borden Ink plant in Depew, New York. In this same period KISS's management decided to add bonus items to the albums. There would be posters, stickers, fake tattoos, trading cards or booklets inserted into the album sleeve, which resulted in an appealing visual and tactile package. They would also add an order form with 
which fans could buy more merchandise through the official fan club. ${ }^{6}$ The creation of this mythology increased and amplified KISS's superstar cult status, which was yet another tool used to capitalize on KISS's success.

While the group affirmed their platinum status with follow-up albums Rock and Roll Over (1976) and Love Gun (1977), and continued to tour the world, the KISS management came up with another commercial plan: one that was initiated to keep the band together in times where internal tensions were bringing them to the edge of a break-up. The intense touring schedule, as well as the abuse of alcohol and drugs by members Peter Criss and Ace Frehley, caused management to come up with a crisis management strategy. The decision was made to let each member do a solo album. This gave each the opportunity to work on their own music and production without the intervention of the other members, and was intended to release tensions among them. And, besides that, the plan provided an elaborate marketing tool, as the albums would be released simultaneously. On September $18^{\text {th }} 1978$, the KISS members each released their individually produced solo albums. To preserve the illusion of unity, the four recognizable painted faces were portrayed on each album in a similar style. Record label owner Neil Bogart revealed in an interview in the LA Times that the 2.5-million-dollar advertising campaign was to make sure that 8 million albums were available in record stores around Christmas. The solo albums reached the Top 50 of the Billboard Album Charts and the shipments alone caused the albums to acquire platinum status in advance (Lendt 1997: 95). ${ }^{7}$

By the end of 1978, the KISS hype had reached its climax. Through advertising campaigns, the market had been flooded with KISS merchandise: clothing, toys, albums, films and all sorts of consumer products were available with the KISS brand attached to them. The only way to continue this success was to build upon the existing KISS image in ways that could reach a wider range of demographics. According to Chris Lendt (1997: 97): "KISS wanted to expand their role as icons of pop culture, like Disney characters. Bill [Aucoin] and KISS felt they should widen their audience, reaching out beyond the hard rock fans that had been the base for their past success". KISS's carefully constructed dark and "dangerous" image of the early years was altered and softened in an attempt to provide family entertainment. It was a choice the die-hard fans could not accept, and many loyal fans definitively dismissed the band. These fans also stopped going to KISS shows, and the lower attendance rates caused heavy financial losses on the huge staging productions that the KISS circus had become.

KISS's seventh studio album Dynasty (1979) and the success of the global disco hit single "I Was Made for Lovin' You", provided a short-lived commercial upturn. But with KISS's genuflexion to the disco craze it had drifted from its initial vision and hard rock identity. Besides that, the abundant and extravagant live shows, which incorporated the most advanced and costly laser techniques, became unprofitable due to dwindling ticket sales. And because of its magnitude, a KISS show was hard to transport. "It had become more like a mammoth militaryindustrial project, than a road show", as Lendt (1997: 100) puts it. Because of this, KISS's management used an economies of scale strategy, in which two (or more) shows on the same location were planned to cover costs and to minimize logistic difficulties. 
However, there was simply too little interest. KISS's fans could no longer identify themselves with the group's image and music. Simultaneously, as postpunk, new wave, and new metal sub styles emerged, the popularity of glam rock declined. KISS had reached its commercial potential and internal conflicts within the band, amplified by drug and alcohol abuse, caused the departure of drummer Peter Criss in 1980. This departure would mark a change in the success and the audience reception during the 1980s. After KISS had to endure another personnel change in 1982 when guitarist Ace Frehley left, KISS decided in 1983 to continue their music career without their trademark make-up, as the band needed to reinvent itself. KISS lived through the 1980s and the first half of the 1990s with variable success, partly due to the popularity of glam metal in the latter half of the 1980s. However, KISS would never re-achieve the popularity and commercial success they had gained in the latter part of 1970s... until 1996.

\section{1996: the second coming}

You know how the Grammys used to be, all straight-looking folks with suits. Everybody looking tired. No surprises. We tired of that. We need something different... something new... we need to shock the people... So let's shock the people! (Shakur 1996)

With this introduction, rapper Tupac Shakur invited the four original KISS members - in full costumes and make-up - on to the stage at the $38^{\text {th }}$ Grammy Awards. This appearance marked the beginning of a full-scale reunion tour that would take place under the guidance of new KISS manager Doc McGhee. In the remainder of this article I will analyse how KISS regained commercial success, and show that the exploitation of modern media synergy, nostalgia and mythologisation thwarted audience expectations of KISS's live performance. I will explicate how the synergetic relationship between this and live performance provided the conditions for auratic experience. The questions I am concerned with here are: how do media contribute to a reality that transforms audience perception and subsequently evokes craving for auratic experience? And in what way did audience perception (that is, fan experience) create the circumstances that allowed KISS to become successful once again? I shall illuminate these issues and explore how a well thought-out marketing plan can manipulate this audience perception and appeal to past sentiments and nostalgic illusions.

The plan for the KISS reunion tour was born during the KISS Convention Tour in 1995. During these conventions KISS's history and legacy was celebrated, with a few hundred fans in attendance at each of several North American convention and congress centres. For the most fanatical long-term fans, this was a unique opportunity to share feelings of nostalgia and childhood sentiments. With the rise of the Internet, online forums emerged where fans would meet, discuss experiences or music, and inform each other about activities. The KISS conventions were a "gathering of the tribe", modeled after the Star Trek conventions that have been popular among dedicated fans since the 1970s. During the convention, original and rare band memorabilia were displayed, such 
as costumes, stage props and instruments. There would also be a collector trade fair and KISS cover bands playing. Furthermore, KISS would play a short acoustic set themselves, after which there would be an opportunity for fans to ask questions during an informal Q\&A session.

At the convention show in the Los Angeles Hilton, Peter Criss was asked to perform and sing one of his original KISS songs, joining the current line-up on stage. This once-only occurrence was so well received by fans and press that KISS was asked to perform a concert for the MTV Unplugged sessions in 1995, which were highly popular in the early 1990s. Original members Peter Criss and Ace Frehley were asked to join in for a few songs in this show. Again, reaction was so positive that the original four band members officially reunited the following year and announced a full reunion tour. Of course, personal thoughts were very important in considering this undertaking, as Paul Stanley (2014: 349) recalls: "To me, there seemed to be sufficient good feelings to explore the possibility ... I also thought a reunion might provide closure". Another factor was the manner in which the Internet had changed the rules within the music industry. "[A]s it becomes increasingly difficult to generate revenues from the sale of recorded music, it is the live sector which increasingly provides a means of survival for most acts," as Music Week journalist Jim Larkin (2006: 10-11) remarks. KISS and their management were sensitive to the commercial possibilities that live performance would offer in the new digitalized music economy, particularly considering that KISS was always primarily a live band whose performance aesthetics emphasized visual and aural spectacle. The music and the merchandise were one side of the story. But one had to be present at a concert to be fully immersed into the KISS experience.

As Fabian Holt (2010) has shown, live experience and particularly live music have gained cultural value in the post-digital era. Holt argues that, despite mediation and manipulation of sound and visuals, liveness remains increasingly important to many fans. This increasing societal valorisation of liveness in a period of digital saturation is a concept that is interesting for KISS, for they have increasingly created the expectation of liveness while simultaneously becoming increasingly mediated. This proved to be a very effective marketing strategy for the reunion tour. KISS promoted themselves as the resurrection of legends, and the concerts in the tour were promoted as a once-in-a-lifetime experience that no one would want to miss. Re-invigorating the 1970s KISS myth for the radically altered music industry of the 1990s would disclose an unprecedented earning model. In his autobiography Face the Music, Paul Stanley (2014: 350) recalls:

Given the way concert guarantees and tour merchandising had evolved - this was the era when concert ticket prices suddenly shot up - it was hard to imagine anything like the conventions competing with the windfall of a reunion tour in makeup. It seemed like a no-brainer to me. ... No matter how successful we were in the present, without makeup, I knew there was nothing that could compete with what we had been. The myth. The legend. Once upon a time.

The band realized that they had created a legend with their success in the 1970s and saw opportunities to capitalize on this sentiment. KISS's reputation as a live 
act and the recreation of the superhero aura resulted in sold out concerts. In 1996, it was the band's live reputation that was utilized as a marketing strategy once again. This time, however, KISS had to meet expectations or maybe even exceed them. As Stanley states: "[W]e didn't have to be as good as we used to be. We had to be as good as people thought we were" (Leaf 2003: 113). Therefore, an intense touring schedule and promotional strategy was developed in collaboration with KISS's new manager and marketing strategist Doc McGhee. McGhee had previously worked for bands like Bon Jovi and Mötley Crüe, and had a vision for KISS. He understood that KISS's success as a live act in the 1970s was the result of a shrewd marketing plan - a marketing strategy that had to be reinvented and redesigned to meet 1990s media standards. The myth was created once again. Paul Stanley (2014: 360):

I knew it was going to be a big tour, but I didn't see it at that scale ... Doc clearly knew something we didn't. He was coming off mega-tours with Bon Jovi and Mötley Crüe, and he knew that perception would become reality if people bought into it. Luckily, we deferred to him.

The remarkable phrase here is that Stanley states that perception would become reality if people believe the story. In other words, when the fans believe the hype, the illusion will become reality. As I have tried to illustrate above, it is precisely this interplay in which auratic presence is constructed. When negotiated through media and marketing synergy, the aura is not lost, but can be deployed and called upon. In fact, it is applicable in ways that would be unthinkable for Walter Benjamin.

\section{Mega Act 2.0: the most recognizable band in the world?}

By some estimates, KISS are the four most recognized faces on planet Earth. I'll prove it to you. Do you know what the king of Sweden looks like? That's funny, because everybody in Sweden knows what KISS looks like. Gene Simmons (CNN 2011: web source)

In September of 1998 the reunited KISS released their $18^{\text {th }}$ studio album, Psycho Circus. The album entered the charts at number three in the Billboard 200 (Caulfield 2009) and was awarded gold status on $22^{\text {nd }}$ of October 1998 by the RIAA (RIAA 2016: web source). Despite their prominent visual presence on the album cover, the musical contributions of Peter Criss and Ace Frehley were minimal. Studio musicians - who remained unnamed on the album - recorded most of the drums and guitars due to the fact that Frehley and Criss "wouldn't cut it as players", as engineer Mike Plotnikoff put it (Leaf 2003: 409). To the outside world, however, the illusion of unity was kept alive and the consequent Psycho Circus Tour was a financial success, grossing 43.8 million dollars in revenue (Gooch and Suhs, 2002).

After this tour, in early 2000, KISS announced their Farewell Tour, which was supposed to be the last tour of the band. In reality, it would not turn out to be the 
band's farewell but simply, yet again, the departure of Peter Criss and Ace Frehley. With Paul Stanley and Gene Simmons as the entrepreneurial bandleaders on one side, and Criss and Frehley as the classic rock and roll aesthetic representatives on the other, the original KISS line-up was bound to break up once again. This time, however, there was one important difference: KISS and their management realized that the band would be able to continue as long as they maintained their trademark makeup. This realization came after a situation in 1997, when drummer Peter Criss was too sick to perform at a show in Columbus, Ohio. KISS decided to continue the show with Criss replaced by his drum technician Eddie Kanon, who was familiar with the repertoire. In full makeup and costume, Kanon replaced Criss. It worked, and Paul Stanley (2014: 370) remembers the show: "Eddie shaved and put on Peter's makeup. One, two, three, four, let's go - we launched into the show. I introduced Eddie from the stage and ... either nobody cared or nobody had time to care". Peter Criss ultimately left the group at the end of 2001, followed by the departure of Ace Frehley in 2002. Drummer Eric Singer and former KISS road manager Tommy Thayer replaced them, and would now wear their predecessors' characteristic makeup.

Because of this development, KISS and their management realized that the universal appeal of KISS's personas was strong enough to survive on its own, regardless of who wore the costumes and the makeup. As a brand, the characters had their own legitimacy. The realization that KISS's personas represent more value than the actual people behind them was an important commercial turning point for the group. "KISS is a brand, not a band. ... In the land of merchandise KISS is always just KISS. It's the white-faced likenesses of the band's signature characters that matter, not the men behind them", as Gene Simmons underscores (Rolling Stone 2014: web source). This is why, for several years now, there has been discussion about the continuation of KISS without any of the original members. Gene Simmons (1949) and Paul Stanley (1952) are now 67 and 64 years old, respectively, and realize they will physically not be able to perform the energetic live shows for much longer. KISS could potentially last generations as a brand. The iconic KISS masks constitute a recognizable cultural identity in which the rock aesthetic is unified with the super hero image, a fantasy cult, and the accomplishment of the American Dream. ${ }^{8}$

\section{Branding, licensing and merchandising}

KISS was the first band to ever trademark their faces. It's in the Library of Congress. Which is why 35 years later there are literally thousands and thousands of things with our faces on them, anything from KISS M\&Ms to KISS Mr. Potato Heads and KISS Visa cards. We have KISS Kondoms and KISS Kaskets. We'll get you coming, we'll get you going. Gene Simmons (Waddell 2009)

KISS's substantial growth as a brand empire is partly the consequence of the increased global cultural dynamic. The new millennium was the beginning of an era in which increasingly ambitious multi-national brand licensing deals would be made, and in which the KISS brand would be connected to a large and diverse 
number of products and companies, modelled after the business models of enterprises like Walt Disney and Star Wars. KISS partnered with companies such as Canon, Wal-Mart, Dr. Pepper, Pepsi, VISA, 7-Eleven, the animation series Family Guy, and Hello Kitty, to name just a few. KISS-licensed products exceed 3000 in number - an exhaustive list including condoms, coffins, lighters, lottery tickets, cars and KISS cruises (Global Licence 2011: web source). Cultural expansion such as the reality show Gene Simmons' Family Jewels, co-star acting, (auto-biographical) books, a Jon Varvatos clothing line, the opening of the restaurant chain Rock'n'Brews, and KISS's own American football team L.A.KISS all contribute to the capitalization of the KISS myth and the building of the global KISS franchise.

The new possibilities afforded by modern digital reproduction and other technological developments served as the perfect tool to market KISS's products. While other artists, especially in the rock genre, very often had reservations about connecting their name to commercialized products, KISS and their managers have always seized that opportunity. More than ever before, the KISS members have become entrepreneurs. "It is one thing to be passionate about making music, but you can do that in the privacy of your home", according to Paul Stanley (2012: web source). If you want to survive in the music business you will have to capitalize on your creative output: "Music and business go hand in hand. Because if they don't, somebody else will be making your money for you. So, I don't think that it negates, or takes away from, the commitment or love that I have for music". For KISS, music, artistic integrity, and capitalism do not necessarily exclude each other, but are all conditions for a successful music career in modern neoliberal society.

\section{Conclusion}

Here is where the aura resides - not in the thing itself but in the originality of the moment when we see, hear, read, repeat, revise. (Davis 1995)

Walter Benjamin's notion of aura has to be reconsidered in the modern age. Due to technological innovations, especially in the area of digital mediation, the rules have changed and aura is no longer restrained to one location. The reproduction possibilities can result in a multitude of "originals". I endorse this theory, but I also take it a step further and claim that the perception of aura can be scripted, invoked, and subsequently exploited as a marketing tool. It is a tool the music industry needs in order to survive after the submerging assault it has had to endure in this post-Napster era. In the modern medial environment an artist and his/her work exists and interacts within digital networks, creating a kind of omnipresence. The innumerable amount of distribution channels can be used to create a sense of desire, something I would like to call "auratic promise". The audience redeems this auratic promise in attending the ultimate unique and "one-off" musical experience in the here-and-now: the live performance.

In this article I have argued that auratic experience manifests itself in the dynamic interplay between artistry, marketing, live performance, spectacle, and 
mythologisation. Interestingly, the live performance experience is more popular than ever in the modern digital age. Live music and live experience are of invaluable importance in people's lives, and offer new financial possibilities for the viability of the music industry. In this context KISS has proven an interesting case study. KISS has pioneered a new music business model by revealing how a music group can commercially exploit its brand, and was also one of the first live acts to fully embrace marketing possibilities, benefitting from their alter ego creations. In over four decades, KISS has built a strong and fanatical international following, in which the synergetic dynamics of media hype, digitalization and globalization played important roles.

As we have seen, KISS fans not only invest in the music, but in the myth surrounding the band as well. The gathering of KISS fans - online as well as in real-life - takes on an almost religious character. The "KISS Army" are perceived as the most fanatical fans a band could have, many collecting every piece of merchandise available, tattooing their bodies with the KISS images, and travelling around the world to follow the band everywhere - and spending a lot of money doing so.

Since the 1970s, KISS has continuously set a high standard for live performance, providing a multi-sensorial experience. Bombs, lights, smoke, theatrics, multi-media screens and moveable stage parts come together in a Wagnerian Gesammtkunstwerk in which the auratic comes to life. This auratic experience is evoked by the live show's substantive qualities, among which the interplay of proximity and distance are of special importance. Though spatially within reach - sometimes literally - the icons on stage are seen as inviolable, which is enhanced by spectacle and the aforementioned show elements. The live performance spectacle is the auratic experience which fans have anticipated, and it is where they witness the "original work of art" in the here and now. This reminds one of Walter Benjamin's (2008: 9) description of auratic quality, which he depicted "as a unique manifestation of a remoteness, however close it may be".

\section{Endnotes}

${ }^{1}$ For this article I shall use two translations of Benjamin's 1936 work, one in English (2008a) and one in Dutch (2008b).

2 One can think of art in which there is no "original" and therefore no "reproduction", such as music downloads, digital photography or perhaps the work of Jeff Koons, whose reproductions of (banal) objects involve dozens of employees in the process of creation.

${ }^{3}$ Auslander (2008: 96) adds: "It is also a result of industrial practice: the music industry specifically sets out to endow its products with the necessary signs of authenticity".

${ }^{4}$ KISS got its first major success in Detroit, MI, an area where people working in the industrial sector were arguable more liable to let of steam by way of a theatrical largerthan-life rock concert than elsewhere.

${ }^{5}$ Also, according to Billboard rock concerts draw a larger audience than any other music genre (Dome and Wall 1985). 
${ }^{6}$ This sales strategy proved to be an enormous financial success - KISS's gross income in 1977 was estimated around 10.2 million dollars (Lendt 1997: 88).

${ }^{7}$ Not long after the release of the solo albums, the RIAA changed the rules for awarding platinum status: only sales would allow the platinum status to be awarded, not shipments alone.

${ }^{8}$ Gene Simmons relates in various interviews how he, as an eight-year old boy, and his mother emigrated from Israel to the US and made his American Dream come true. He also describes this in length in his autobiography (Simmons 2003).

\section{References}

\section{Bibliography}

Adorno, T. W. 2002. Essays on Music, edited by T. Leppert, Berkeley, CA: University of California Press.

Attali, J. 1985. Noise: The Political Economy of Music. Minneapolis, MN: University of Minnesota Press.

Auslander, P. 2008. Liveness: Performance in a Mediatized Culture. London and New York: Routledge. Second edition. 2006. Performing Glam Rock: Gender and Theatricality in Popular Music. Ann Arbor, MI: The University of Michigan Press.

Barfoot C. E. 2011. Rock Brands: Selling Sound in a Media Saturated Culture. Plymouth: Lexington Books.

Benjamin, W. -

2008a. The Work of Art in the Age of Mechanical Reproduction. London:

Penguin. Translated by J. A. Underwood.

2008b. Het Kunstwerk in het Tijdperk van zijn Technische

Reproduceerbaarheid. Amsterdam: Boom. Translated by Henk Hoeks. Third revised edition.

Caulfield, K. 2009. Kiss, Buble Battle for no 1 on Billboard 200. Billboard, 10 August. http://www.billboard.com/articles/news/267144/kiss-buble-battle-forno-1-on-billboard-200; Accessed: 14 September 2016.

Bolter, J. D., Macintyre, B., Gandy, M. and Schweitzer, P. 2006. New Media and the Permanent Crisis of Aura. Convergence: The International Journal of Research into New Media Technologies 12 (1): 21-39.

CNN. 2011. The Most Recognizable Band on Earth? Inside the world of KISS inc. CNN. http://money.cnn.com/2011/10/18/news/kiss_products/; Accessed: 14 September 2016.

Davis, D. 1995. The Work of Art in the Age of Digital Reproduction (an Evolving Thesis: 1991-1995). Leonardo 28 (5): 381.

Dome, M. and Wall, M. 1985. World View: Metal Crusade in Global Gear. Billboard, 27 April: 12. 
Frith, S. 2007. Live Music Matters. Scottish Music Review 1(1): 1-16.

Global Licence 2011. Kissonomics. Global Licence!

http://www.licensemag.com/license-global/magazine-archive; Accessed: 16 September 2016.

Gooch, C. and Suhs, J. 2002. Kiss Alive Forever. New York: Billboard Books.

Holt, F. 2010. The Economy of Live Music in the Digital Age. European Journal of Cultural Studies 13 (2): 243-261.

Kahn-Harris, K. 2007. Extreme Metal: Music and Culture on the Edge. New York: Berg.

Larkin, J. 2006. Live Boom Raises Data Questions. Music Week, 11 March: 10-11.

Leaf, D. and Sharp, K. 2003. Kiss: Behind the Mask: The Official Authorized Biography. London: Warner Books.

Lendt, C. K. 1997. Kiss and Sell: The Making of a Supergroup. New York: Billboard Books.

RIAA. 2016. Gold and Platinum. RIAA. https://www.riaa.com/goldplatinum/?tab_active=default-award\&ar=KISS\&ti=PSYCHO+CIRCUS; Accessed: 16 September 2016.

Rolling Stone. 2014. Kiss Forever: 40 Years of Feuds and Fury. Rolling Stones. http://www.rollingstone.com/music/news/kiss-forever-40-years-of-feuds-andfury-20140326; Accessed: 14 September 2016.

Sharp, K. 2013. Nothin' to Lose: The Making of KISS (1972-1975). New York: HarperCollins.

Simmons, G. 2003. KISS and Make-up. London: Arrow Books.

Something Else. 2012. Beatles on Steroids. http://somethingelsereviews.com/2012/10/08/the-beatles-on-steroids-genesimmons-says-kiss-builds-off-the-fab-fours-template/ Accessed: 14 september 2016.

Stanley, E. n.d. Alive and Well. Epic Rights. http://www.epicrights.com/home/alive-and-well; Accessed: 4 January 2016.

Stanley, P. 2014. Face the Music: A Life Exposed. New York: HarperOne.

Waddell, R. 2009. The Billboard Kiss Cover. Billboard, 10 July. http://www.billboard.com/articles/news/267151/gene-simmons-the-billboardkiss-cover; Accessed: 7 January 2016.

Walser, R. 1993. Running with the Devil: Power, Gender, and Madness in Heavy Metal Music. Middletown, CT: Wesleyan University Press.

Weinstein 1991. Heavy Metal. New York: Lexington Books.

\section{Discography}

Aerosmith. 1978. Live! Bootleg. Columbia Records, USA.

Cheap Trick. 1978. Cheap Trick at Budokan. Epic Records, Japan.

David Bowie. 1970. The Man Who Sold the World. Mercury Records, USA.

KISS -

1975. KISS Alive! Casablanca Records, USA.

1976. Destroyer. Casablanca Records, USA.

1976. Rock and Roll Over. Casablanca Records, USA. 
1977. Love Gun. Casablanca Records, USA.

1979. Dynasty. Casablanca Records, USA.

1998. Psycho Circus. Mercury Records, USA.

Peter Frampton. 1976. Frampton Comes Alive, A\&M Records, USA.

\section{Videography}

Stanley, P. 2012 Interview Paul Stanley with WS Celebrity Business Reporter Lee Hawkins. http://www.youtube.com/watch?v=JrMUR1RhTjU; Accessed: 15 September 2016.

Shakur, T. 1996. Tupac Presenting The Grammy 1996 With Kiss.

https://www.youtube.com/watch?v=OTfzmJT8m1s; Accessed: 2 September 2016. 